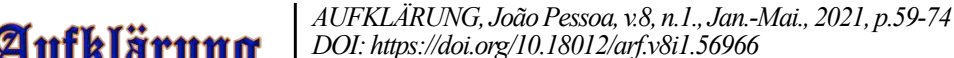 \\ Recebido: 22/12/2020 | Aceito: 12/04/2021 \\ Licença: Creative Commons 4.0 International (CC BY 4.0)
}

\section{O INSTANTE REVOLUCIONÁRIO DA JETZTZEIT}

\author{
[JETZTZEIT'S REVOLUTIONARY MOMENT]
}

Deborah Spiga *

Universidade, Paisi

\begin{abstract}
RESUmo: Objetivo deste artigo é mostrar qual é o papel desempenhado pelo presente na temporalidade benjaminiana e como, através da Jetztzeit, o presente pode ser revolucionado e o passado resgatado. Jetztzeit é o tempo congelado que se precipita no instante, tempo condensado em imagens que contêm passado e presente em uma constelação que rasga $o$ horizonte do continuum historicista. Analisaremos as diversas ocorrências com os quais esse conceito-imagem aparece nas Teses, nos referiremos à "dialética em estado de interrupção" e à chance revolucionária com uma constante referência à visão pessoal do materialismo histórico do autor e à suas obras juvenis.
\end{abstract}

Palavras-chaVe: Jetztzeit; passado; presente; imagem dialética

\section{O PRESENTE E A JETZTZEIT}

ABSTRACT: The purpose of this article is to show what is the role played by the present in Benjamin's temporality and how, through Jetztzeit, the present can be revolutionized and the past rescued. Jetztzeit is a frozen time that precipitates in the moment, time condensed in images that contain past and present in a constellation that rips the horizon of the historicist continuum. We will analyze the different cases with which this concept-image appears in the Theses, we will refer to the "dialectic in a state of interruption" and the revolutionary chance with a constant reference to the personal view of the author's historical materialism and his youthful works.

KEYWORDS: Jetztzeit; past; present; dialectical image

etztzeit, "tempo-agora"1, "o atual"2, "o agora"3. Este termo em alemão
significa simplesmente o "hoje", o "presente" em seu significado mais comum e atual. A Jetztzeit aparece pela primeira vez na tese XIV. Esta temporalidade não apenas representa a necessidade de ruptura com o tempo linear, homogêneo e vazio típico do historicismo, ao qual Benjamin contrapõe um tempo "carregado" e integral; mas também à necessidade de um desmascaramento da tradição positivista-evolucionista que vê nos fatos históricos implícitas ligações causais semelhantes àquelas usadas no estudo dos fenômenos naturais, para os quais o que vem depois é necessariamente causado pelo que vem antes em uma linha da qual se perde completamente de vista o começo ${ }^{4}$. Para o historiador materialista, ao contrário, é através de uma visão

* Doutorado em andamento em Filosofia (Conceito CAPES 4), na Universidade Federal de São Paulo, UNIFESP, Brasil. Mestrado em Scienze filosofiche pela Università degli Studi di Sassari (2011.E-mail: deborahspiga@hotmail.it 
retrospectiva, é com aquilo que aconteceu depois, mesmo depois de milhares de anos, que podemos dar a aqueles eventos históricos a importância histórica que eles antes não tinham. É assim que o materialista histórico: "apreende a constelação em que a sua época chegou ao encontro com uma época anterior bem definida" (BENJAMIN, 1997, p. 57. Tradução nossa). A Jetztzeit é apenas essa constelação. Embora se refira ao presente, é a capacidade que um dado passado possui de viver além de sua própria época e revolucioná-la. É a figura do "sincrônico" (DESIDERI, 1995, p. 160. Tradução nossa), o tempo que se aglomera em um "momento" e pressiona com sua urgência. O que é apresentado é um "encapsulamento do futuro no passado" (BODEI, 1983, p. 92. Tradução nossa). É precisamente quando o passado e o futuro se encontram que a centelha da Jetztzeit golpeia e que se pode revolucionar o presente e redimir o passado de opressão ${ }^{5}$. A Jetztzeit é o "pacto secreto" que liga um momento específico do presente a um momento do passado. É este "Tempo-agora" que aglutina a história do passado como em uma grande concentração, que desmonta o turbilhão da história; este é uma "abreviatura grandiosa que sintetiza, nos seus momentos mais elevados, toda a história da humanidade" (DESIDERI, 1995, p. 51. Tradução nossa).

A Jetztzeit também indica como nem tudo o que foi no passado se torna presente em uma sucessão linear, mas como há sempre uma espécie de classificação pela qual o que é "presente" é sempre conciliador com aquele "butim" do patrimônio cultural em que se encaixa. A serem cortados, de fato, são todos aqueles "descontínuos" e aquelas falhas que ameaçam o fluxo do continuum. Verdadeiro detonador, o Jetztzeit é capaz de explodir essa falsa continuidade da história, desmontar sua montagem oficial mostrando detalhes escondidos e versões heterogêneas aniquiladas. Assim Fabrizio Desideri o descreve:

O jetzt do presente é o fio que liga diferentes áreas e faces do passado; depois de tê-lo desligado do Begriff da história como continuum, depois de tê-lo "citado" fora do lugar onde a sua "duração" coincide em não ter nome, em ser aniquilado pela mediação do tempo - como mediação do já concebido em processo decompõe suas saliências peculiares, fixa seu devir em conceito, em estado (DESIDERI, 1995, p. 160. Tradução nossa).

Poderíamos dizer que, para Benjamin, de fato, o percurso histórico não se esgota nos seus conceitos estáticos, mas encontra-se em um estado de "tremor", "movimento imperceptível" e síncope que desestabiliza as quadraturas típicas da historiografia tradicional. O presente que assim se forma não é aquele eternamente dilatado ou empurrado para um futuro definitivamente melhor, mas nem mesmo "passagem". Ele, em vez disso, é caracterizado por um "excedente" (MORONCINI, 1994, p. 114. Tradução nossa) constitutivo, por um "remanescente" que o desmarca. O presente é atravessado por estilhaços que no passado antecipam o futuro, por um conjunto de fios que na sua urdidura revelam a trama do passado. E para essa tarefa que o historiador materialista deve se preparar, ele deve olhar, segundo Benjamin, para:

uma ciência da história que não tem mais por objeto um emaranhado de fatos puros, mas aquele conjunto definido de fios que representa a trama de um passado na urdidura do presente. (Seria errado querer identificar este enredo com o mero elo de causa e efeito. Em vez disso, este enredo é todo de tipo dialético, e é possível que durante séculos certos fios se tenham perdido para que o curso atual da história recomece repentinamente e quase inadvertidamente). (BENJAMIN, 1996, p. 14. Tradução nossa). 
A metáfora dos fios chama a memória a imagem da cabeça com cabelo trançado nos Materiais Preparatórios ${ }^{6}$ às Teses:

Só quando o curso da história desliza suavemente pelas mãos do historiador é que é legítimo falar de progresso. Se, por outro lado, é uma corda muito puída e enroscada em mil meadas que pendem como tranças soltas, nenhuma delas tem lugar determinado antes de todas serem reunidas e enredadas no penteado da cabeça. (BENJAMIN, 1997, p. 94. Tradução nossa).

Somente na dialética da trama, e não em uma única corda que corre suavemente "ao longo das trilhas do progresso", podemos ver a verdadeira trama do passado. Somente assim podemos perceber como alguns fios que, em seu tempo, não encontraram o lugar certo o tomam em outro momento histórico. Neste ponto, porém, não é o futuro dos adivinhos que deve ser profetizado, mas justamente aquele presente que, no momento em que tentamos apreendê-lo, corre o risco de já ser ultrapassado e esquecido em uma perspectiva "infuturante". Assim como o político de Turgot ${ }^{7}$ o historiador materialista deve prever o presente que irremediavelmente escapa dele e já se tornou passado. Ele pode conhecer a "verdadeira imagem do passado" não por meio de um procedimento simplesmente aditivo, pelo qual cada evento histórico vem adicionado ao sucessivo em uma cadeia de infinitos pontos e nem através de um "egocentrismo interpretativo" (GAGNEBIN, 1993, p. 39), segundo o qual se pode reencontrar o passado através de uma projeção ilusória dos pontos em comum entre passado e presente; mas apenas por um tempo feito de "paradas", suspensões e epoché que resgatam os acontecimentos de não poderem ser de outra forma e de sua fixação em conceitos $^{8}$. Assim Benjamin fala a respeito disso em Eduard Fuchs, o colecionador e o historiador:

Se para o materialismo histórico o conceito de cultura é um conceito problemático, a divisão da cultura em um complexo de bens que se tornaram objetos de posse da humanidade é em si uma ideia inconcebível. A obra do passado não é para ele uma obra acabada. Ele não vê isso caindo no colo de qualquer idade (ou qualquer parte dela) como uma coisa para manusear. [...] O conceito de cultura mantém um aspecto fetichista para o materialismo histórico. A cultura parece-lhe reificada. A sua história seria simplesmente a escória que nos momentos memoráveis, desenterrada na consciência do homem por uma experiência que nada tem de autêntico e nada de político, eles depositaram. (BENJAMIN, 1996, p. 91. Tradução nossa).

O "conceito de cultura" e de patrimônio cultural é de fato problemático para Benjamin porque sempre revela a supremacia de uma classe dominante e a eliminação da classe dos vencidos. Armazenar ou "monumentalizar" os bens dos oprimidos em museus, arquivos e exposições não faz nada além de fixar este conteúdo, ocultar seus vários impulsos revolucionários e catalogá-los como posse silenciosa. $\mathrm{O}$ historiador materialista, ao contrário, não apenas não vê no passado algo concluído, nos fatos algo que pode ser arquivados, nos objetos algo a ser incensado, mas também vislumbra naquilo que os "historiadores clássicos" praticam, uma verdadeira "história reificada". A única esperança então está em desenterrar, "descolar, por assim dizer, o núcleo do passado de um invólucro de imagens pré-fabricadas que nos impedem de percebê-lo em sua verdade" (GAGNEBIN, 1993, p. 52) e trazer à luz aquela "escória de momentos memoráveis" que a cultura oficial primeiro negou e depois escondeu. Para o historiador materialista se torna necessário então o choque do momento: 
articular o passado historicamente significa: reconhecer no passado o que coincide na constelação de um momento único e idêntico. Em outras palavras, é o Jetztzeit é o que rompe aquele fluxo catastrófico da humanidade ignorante e sonhadora em direção àquele presente infuturante e esquecido de seu próprio passado. O conhecimento histórico é possível unicamente e exclusivamente no momento histórico. (BENJAMIN, 1997, p. 95. Tradução nossa).

O materialista histórico deve captar esses sinais rapidamente na oscilação e no lampejo de uma imagem. Deve aproveitar aquela oportunidade que se apresenta no momento e que corre o risco de se perder irremediavelmente, sua deve ser a oportunidade do "tempo kairológico" (MARRAMAO, 2008, p. 106. Tradução nossa). Isso porque própria da "verdadeira imagem do passado" é uma transitoriedade intrínseca que a retira de toda aparência. Não é de um "olhar puro" que o historiador materialista precisa, mas de uma "presença de espírito" que lhe permita captar e zelosamente vigiar esse vislumbre fugaz do mais próximo com o mais longínquo. O que Benjamin prospecta é uma reversão de direção, que tire do passado sua dimensão de "já estado", de definido e concluído e o abre, através de sua repetição no presente, ao seu resgate possível. É necessário tornar presente o que "nunca foi", mas não para completá-lo como um ressuscitado, mas como uma peça que falta e que é trazida à luz do esquecimento em que foi aprisionada. Isso é possível porque a história "não é apenas uma ciência, mas também, e não menos uma forma de rememoração" (BENJAMIN, 1997, p. 121. Tradução nossa). É a memória do "nunca existido" que pede justiça, aquele inacabado que agora pede para ser feito, resgatado e recuperado. $\mathrm{O}$ "nunca existido" em questão não é o da memória consciente, do negativo e da "relíquia", mas aquele que num "piscar de olhos", nos sacode com a sua impetuosa "atualidade" e pode nos permitir a libertação do passado. Este tempo é muito próximo do tempo perdido de Proust, ou seja, do que não era quando era, do que nunca se tornou uma "experiência vivida". Assim Benjamin descreve o tempo proustiano:

A eternidade da qual Proust revela alguns aspectos não é o tempo ilimitado, mas o tempo entrelaçado. O que realmente importa para ele é o curso do tempo em sua forma mais real, isto é, entrelaçado com o espaço, que em nenhum outro lugar domina tão inalterado como na memória, internamente, e na senescência, externamente. [...] O procedimento de Proust não é reflexão, mas tornar presente. Ele é dominado pela verdade de que nem todos temos tempo para viver os dramas da existência que nos são destinados. É por isso que envelhecemos - por nenhuma outra razão. As rugas e rugas do nosso rosto são os cartões de visita das grandes paixões, dos vícios, dos conhecidos que passaram por nós - mas nós, os anfitriões, não estávamos lá (BENJAMIN, 1993, p. 365. Tradução nossa).

A memória como tempo entrelaçado é a memória que se torna espaço, que se torna descontínua, o tempo das analogias, o tempo da repetição. É o tempo que distancia fisicamente. Não é o tempo da reflexão, ou seja, não é posse morta, mas a memória do não vivido, do que nunca existiu que lampeja e nos mostra a nossa finitude com sua ferida. A memória e a velhice estão, neste sentido, no mesmo nível, ambas mostram a experiência do não vivido. Essa memória do que nunca existiu é a memória coletiva que se torna espaço e cria, como a Jetztzeit, uma brecha no tempo do continuum.

\section{A imagem dialética, A Jetztzeit e O REVOLUCiONÁRIO}


Tendo descrito o particular estatuto da Jetztzeit, neste ponto, poderiamos nos perguntar onde vislumbrar essa particular conexão? Essa temporalidade sui generis "se condensa em imagens que podem ser chamadas de imagens dialéticas. Elas representam uma solução salvadora para a humanidade" (BENJAMIN, 1997, p. 94. Tradução nossa). Representam uma "ligação entre historiografia e política" (BENJAMIN, 1997, p. 94. tradução nossa), que se por um lado modifica o percurso histórico e a forma de compreendê-lo, por outro, conhecendo-o o revoluciona. É ao historiador que é confiada esta tarefa, mas apenas a aquele que abandonou a prostituta do "era uma vez" do historicismo e vê no seu presente não algo a ser superado em vista de um futuro imparável, mas um ponto repentino e fugaz "no qual o tempo está em equilíbrio e parou” (BENJAMIN, 1997, p. 51. Tradução nossa). Somente onde o passado está carregado com o explosivo do "agora" o historiador pode estabelecer o estopim e explodir o continuum da história. Esta temporalidade aparece por meio de "imagens" saturas de sentido e não por meio de uma série de eventos colocados em sequência típica do conto épico. Salienta-se como a necessidade do nosso autor de se expressar em "imagens" pode ser explicada com a necessidade de uma maior concretude da linguagem ${ }^{10}$, que desviando do processo argumentativo filosófico clássico, possa se situar, ao contrário, em uma tensão dialética que não alcança síntese, mas que persiste nesta polaridade. $\mathrm{Na}$ imagem, de fato, não há supremacia do mais distante sobre o mais próximo ou vice-versa, mas um embate real no qual passado e presente se iluminam mutuamente em uma constelação. As imagens são fragmentárias, equivocas e evanescentes e a dualidade delas é evidente no "diferencial temporal" (BENJAMIN, 1997, p. 136. Tradução nossa). Benjamin as compara àquelas imagens do passado que aparecem aos homens nos momentos de perigo, são memórias da memória involuntária. A natureza da imagem é para Benjamin uma "dialética em suspenção" que sincopa a seguimento da temporalidade histórica. Só podemos conhecer o passado através de uma imagem e sua relação se configura como uma "imagem fulgurante", em um clarão em que o "Outrora" e o "agora" formam uma constelação. Ademais, o fato de a imagem ser dialética é emblemático de sua ambiguidade, de fato, ela é sempre uma imagem de outra coisa. Desta forma, Benjamin argumenta sobre isso:

A ambiguidade é a aparência figural da dialética, a lei da dialética em estado de suspenção. Essa prisão é a utopia e a imagem dialética e, portanto, a imagem do sonho. Essa imagem oferece a própria mercadoria: como um fetiche. As passagens, que são tanto a casa quanto a rua, oferecem essa imagem. Essa imagem oferece a prostituta, que é ao mesmo tempo vendedora e mercadoria. (BENJAMIN, 1962, p. 155. Tradução nossa).

O verdadeiro historiador, então, deve ser capaz de interpretar esses sinais, olhar para eles como o astrólogo faz com as constelações e o filólogo com seus textos. Assim Benjamin no ensaio Sobre a faculdade mimética de 1933, citando o verso "Lendo o que nunca foi escrito" da peça de Hofmannsthal Der Tor und der Tod; comenta: "Esta leitura é a mais antiga: a que antecede todas as línguas desde as entranhas, das estrelas ou das danças" (BENJAMIN, 1962, p. 64. Tradução nossa). Assim como a leitura das constelações pressupõe uma "faculdade mimética" com a qual o astrólogo é capaz de comparar afinidades, semelhanças e produzir correspondências imateriais, o historiador deve ser capaz de ler no campo de tensão criado pelas imagens dialéticas a "verdadeira imagem do passado". Em um fragmento do Passagen-Werk, Benjamin também acrescenta que as imagens dialéticas “são imagens autênticas (isto é, não arcaicas); e o 
lugar onde você as encontra é a linguagem" (BENJAMIN, 1997, p. 117. Tradução nossa). Nesta frase podemos averiguar o que mais caracteriza o pensamento benjaminiano, ou seja, a interconexão entre história, imagem e linguagem. Mas a que coisa estaria se referindo Benjamin com o fato de que tais imagens só se encontrariam na linguagem? Para melhor entrever esta relação, voltemos por um momento ao texto de 1933. É aqui, de fato, que podemos ver como o autor descreve o homem como aquele que possui "a maior capacidade de produzir semelhanças" (BENJAMIN, 1962, p. 64. Tradução nossa). O filósofo alemão também conta sobre a existência de uma época antiga em que, entre microcosmo e macrocosmo, reinava uma "lei da semelhança" total que tinha como objetivo estimular os "reatores miméticos" do homem. Ele não tinha outros intermediários, ele lia diretamente no livro da natureza as "semelhanças intangíveis". Essa situação, no entanto, foi mudando, até ser totalmente substituída por um "enfraquecimento crescente da faculdade mimética" (BENJAMIN, 1968, p. 72. Tradução nossa) do homem ao qual permaneceu como único recurso, a linguagem. Esta contínua imitativa no uso da onomatopeia, na análise da grafologia através da qual podemos ler os diferentes traços de caráter até mesmo inconscientes do escritor, ou na semelhança imaterial entre o dito e o escrito; mas Benjamin ressalta:

Tudo o que é mimético na linguagem pode [...] - como a chama - revelar-se apenas numa espécie de suporte. Esse suporte é o elemento semiótico. Assim, o vínculo significativo entre palavras e proposições é o portador em que apenas, em um lampejo, a semelhança se acende. Desde sua produção pelo homem - como a percepção que ele tem dela - é confiada, em muitos casos, e principalmente nos mais importantes, a um flash. Ele pisca. (BENJAMIN, 1968, p. 73. Tradução nossa).

Assim como a imagem dialética nos ajuda a ler e decifrar os traços na polaridade do "Outrora" com o "agora", também por meio da linguagem podemos apreender "correspondências imateriais" entre as coisas. O historiador, portanto, não assume apenas a aparência de um astrólogo, mas também do exegeta que aborda os fenômenos históricos com a perícia do intérprete do texto sagrado nas suas infinitas interpretações ${ }^{11}$ e do antigo narrador que com sua experiência nos monstra como a história é aberta e não inacabada. O fim das interpretações é o mundo da atualidade integral, o mundo messiânico em que a uma história universal corresponde também uma língua universal sem deriva de significado.

Mas voltando às imagens dialéticas, para quem estas são direcionadas? Estas são endereçadas para as classes revolucionárias no instante de sua ação. O papel do historiador materialista é fundamental para esse fim, pois cabe a ele despertar a humanidade do "narcótico" do historicismo, do fracasso do positivismo e prospectar um novo paradigma de leitura da historicidade. Sua tarefa é "escovar a história contrapelo" destruindo o objeto histórico, mostrando como a história é pontuada por cesuras, interrupções e cortes que bloqueiam seu fluxo aparente. Este processo deve ser acelerado e não esperado passivamente. $\mathrm{O}$ passado só pode ser conhecido se for "atualizado" e isso sempre acontece em um "momento de perigo". Este momento dá o "poder das chaves" (BENJAMIN, 1997, p. 55. Tradução nossa) que abre as portas daquelas salas do passado que até então estavam barradas e que agora se abrem, permitindo assim que o fenômeno histórico encontre finalmente seu lugar pleno. Esse flash, essa iluminação acontece em um determinado momento através de uma imagem síncrona. Nesse sentido, não é por acaso que, segundo Benjamin, os revolucionários franceses se inspiraram nas lutas da Roma antiga: "Assim, para Robespierre, a Roma 
antiga era um passado carregado de agora, que ele extraiu à força do continuum da história. A Revolução Francesa afirmou ser uma Roma de volta" (BENJAMIN, 1997, p. 47. Tradução nossa). A Roma Antiga é o "atual" para os revolucionários de ' 89 , no sentido de que ela continha em si alguns brotos não germinados que somente naquele momento voltaram a florescer. Os valores, as esperanças desiludidas, as oportunidades perdidas da Roma antiga, através dos revolucionários franceses, encontram novamente uma chance de possível realização. Significativa a esse respeito é a imagem relatada por Benjamin dos revolucionários aptos a inaugurar um novo calendário. Este último, através de novos dias festivos, novos nomes marca distintamente a diferença entre o novo tempo e o do ancien régime, e, da mesma forma, torna-se o símbolo de uma forma ativa de lembrar. $\mathrm{O}$ calendário se torna assim uma verdadeira consciência histórica ${ }^{12}$. Mas este não é o único exemplo revolucionário que Benjamin cita, de fato, a respeito da revolução de 1830, que levou à abdicação de Carlos $\mathrm{X}$, ele escreve que:

Na revolução de julho houve um episódio em que essa consciência ainda se afirmava. Na noite do primeiro dia de combate, aconteceu que em vários pontos de Paris, de forma independente e ao mesmo tempo, atiraram nos relógios das torres sineiras. (BENJAMIN, 1997, p. 47. Tradução nossa).

Isso só pode ser compreendido se inserirmos a batalha dos revolucionários contra os privilégios da nobreza na perspectiva de uma reapropriação daquele tempo vital do qual eles foram cortados e excluídos. A intenção deles, com aquele golpe, era parar o tempo mecânico marcado pelos poderosos e reiniciar um diferente. Uma revolução, aliás, que nada mais é do que um retorno à origem; não é por acaso que Benjamin coloca o lema de Karl Kraus como epigrafe para esta tese "a origem é a meta". Revolução que é, no entanto, a restauração do que não foi, do que ficou inacabado e que agora, através da sua atualização, tem a esperança de poder se realizar. Revolução que é a esperança na repetição do perdedor da história que, voltando em uma pós-história, pode esperar a sua redenção.

\section{O HISTORIADOR MATERIALISTA E A MÔNADA}

Neste ponto, poderíamos nos perguntar: qual é o principal objeto da pesquisa do historiador materialista e no que difere do historiador oficial? Não se trata de uma busca obsessiva de dados a serem acumulados na perspectiva de uma história universal ${ }^{13}$, mas daquilo que se apresenta na forma de uma mônada:

Quando o pensamento para repentinamente em uma constelação saturada de tensões, causa um choque em força da qual se cristaliza como uma mônada. O materialista histórico se aproxima de um objeto histórico unicamente e exclusivamente quando o encontra como uma mônada. Nessa estrutura ele reconhece o sinal de uma interrupção messiânica do acontecer, ou seja, de uma chance revolucionária na luta em favor do passado oprimido. Ele a usa para fazer com que certa era salte do curso homogêneo da história; assim, ele traz certa vida de seu tempo, certa obra do corpus de obras de um autor (BENJAMIN, 1997, pp. 51-53. Tradução nossa).

Aqui ocorre operar uma reviravolta do método hermenêutico tradicional, segundo o qual uma obra é entendida apenas a partir de seu contexto histórico e cultural e não vice-versa ${ }^{14}$. Isso quer dizer que nosso pensamento deve ser iluminado pela constelação da "verdadeira imagem do passado" que se apresenta no "tempo-agora" e 
se condensa e "cristaliza" em mônadas. Estas são o sinal de suspenção do pensamento e não são históricas, embora elas ocorram no tempo, elas têm algo de ideal, a perspicácia do cristal e as suas mil facetas se refletem em uma. $\mathrm{O}$ historiador materialista só pode conhecer através delas, somente assim pode romper a falsa continuidade da história e dos cânones interpretativos clássicos e construir um novo olhar histórico. Seu trabalho será então semelhante à técnica de montagem, que reconstrói peça por peça como com a técnica do mosaico na antiguidade. Se torna necessária a desmontagem, a destruição, a desintegração do objeto histórico nos seus detalhes para a construção de uma nova síntese dialética. É de uma "micrologia" que o historiador deve partir. Nesse sentido é fundamental que a destruição e a desformalização do tempo siga necessariamente a ars combinatória que a partir dos fragmentos, dos detalhes possa entrever a dimensão do maior em sua tensão ${ }^{15}$. O historiador materialista deve olhar para a mônada como uma estrutura arquitetônica em construção, ele, ressalta Benjamin

\begin{abstract}
tem que erguer apenas uma estrutura sutil, mas sólida - uma estrutura filosófica para capturar em sua teia os aspectos mais atuais do passado. Mas assim como as visões grandiosas oferecidas pela nova arquitetura de ferro da cidade [...] permaneceram por muito tempo privilégio exclusivo dos operários e engenheiros, também o filósofo, que quer aqui adquirir as primeiras perspectivas, deve ser um trabalhador independente, livre de vertigens [...]. (BENJAMIN, 1997, p. 115. Tradução nossa).
\end{abstract}

Além disso, é importante ressaltar, como estas imagens só podem ser lidas em um determinado momento, sua "constelação" de significado só se revela em um determinado momento. As imagens carregam uma marca de historicidade que determina a apresentação e a legibilidade delas. Ao contrário das essências de Heidegger, elas possuem um "índice histórico" (BENJAMIN, 1997, p. 117. Tradução nossa) que determina não apenas a época em que nasceram, mas também aquela em que serão lidas e compreendidas. Existe uma relação especial de sincronia entre as duas: "Cada presente é determinado por aquelas imagens que lhe são sincrônicas: cada agora é o agora de certa cognoscibilidade" (BENJAMIN, 1997, p. 117. Tradução nossa). A Jetztzeit atualizando o objeto histórico vislumbra um novo paradigma, cria um campo de tensão pelo qual por meio de sua dialética, o acontecimento se polariza entre uma pré e uma pós-história sempre de forma diferente e fora de si mesmo, como com uma linha dividida pelo "corte de Apeles"16: "O presente determina no objeto do passado, para apreender o seu cerne, o ponto em que a sua pré e pós-história se desintegrou" (BENJAMIN, 1997, p. 117. Tradução nossa). Neste sentido, para melhor compreender a Jetztzeit, a metáfora que Benjamin usa nos Materiais Preparatórios citando a frase de Focillon sobre o estilo clássico é muito sugestiva:

Um breve momento de plena posse das formas, apresenta-se [...] como uma felicidade rápida, como o Akmé dos gregos: a escala não oscila mais, exceto fracamente. O que espero não é vê-la cair de novo imediatamente, muito menos um momento de absoluta fixidez, mas, no milagre desta imobilidade hesitante, o leve e imperceptível tremor, que me indica que ela está viva. (BENJAMIN, 1997, p. 98. Tradução nossa).

O akmé, literalmente o ápice, a culminação é o ponto de recapitulação máxima, a "plena posse das formas", a síntese do objeto histórico que naquele breve momento fugaz treme imperceptivelmente. Para Benjamin, o historiador revolucionário tem aqui a sua tarefa fundamental porque é ele quem deve apreender o "momento de perigo" e a 
sua oportunidade revolucionária a cada hora. Naquele "agora", naquele "clímax" que promete uma interrupção revolucionária do curso dos acontecimentos, ele prefigura a interrupção messiânica. Cada momento tem sua chance revolucionária, mas somente a condição de que seu significado único e irrepetível seja reconhecido:

[...] não há um único momento (Augenblick) que não traz consigo sua própria chance revolucionária - esta só precisa ser entendida como uma chance específica, ou seja, como uma chance de uma solução completamente nova, prescrita por uma tarefa completamente nova. Para o pensador revolucionário, a chance revolucionária peculiar é confirmada por uma dada situação política. Mas para ele não tira menos confirmação do poder das chaves que um momento possui em uma sala bem definida do passado. Entrar nesta sala coincide inteiramente com a ação política; e é por isso que, por mais destrutivo que seja, é reconhecido como ação messiânica. (BENJAMIN, 1997, p. 55. Tradução nossa).

O revolucionário assume a tarefa dessa ruptura nítida, daquela rachadura posta em prática pela Jetztzeit para desequilibrar a ordem já dada, vingar os oprimidos e mostrar os leques de possíveis esquecidos do passado que não se concretizaram. É através da intervenção política do revolucionário, de fato, que o "tempo agora" se transforma em um momento revolucionário. A nossa "fraca força messiânica" que se revela na memória é contrabalançada pela intervenção secular do revolucionário que obriga a vinda do Messias com sua ação. Os estilhaços da redenção podem, neste sentido, ser apanhados nos momentos da revolução, antecipando assim o Dia do Juízo. A Jetztzeit como "um sinal de uma interrupção messiânica do acontecimento" (BENJAMIN, 1997, p. 51. Tradução nossa) prefigura a vinda do Reino, mas não se identifica com ele, constituindo no máximo um modelo: "resume a história de toda a humanidade numa enorme abreviatura, coincide estritamente com a figura que a história da humanidade faz no universo" (BENJAMIN, 1997, p. 55. Tradução nossa).

\section{O JETZTZEIT NOS ESCRITOS JUVENIS E O PERFIL DO "CARÁTER DESTRUTIVO"}

Podemos ver agora como essa temporalidade particular estava presente em forma germinativa, desde os primeiros escritos benjaminianos: Vida dos alunos e Trauerspiel e Tragédia. É neste último texto de 1916 que se anuncia não só a futura correspondência da linguagem com o tempo retomada no Drama barroco, mas também a futura crítica ao tempo vazio e homogéneo das Teses, aqui representado com a passagem dos ponteiros do relógio: "o tempo da história determina muito mais do que a possibilidade de deslocamentos de certo tamanho e regularidade - isto é, do movimento do ponteiro do relógio - durante deslocamentos simultâneos de uma estrutura mais complicada" (BENJAMIN, 1982, p. 168. Tradução nossa). Neste texto há o contraste entre o tempo histórico e o tempo trágico, entre um tempo preenchido pelo homem e um tempo divinamente realizado. Podemos ver como, segundo nosso autor, o tempo histórico torna-se trágico apenas na figura de grandes indivíduos e testemunhas; da mesma forma, porém, o tempo da história é irredutivelmente incompleto e nenhum acontecimento empírico é capaz de preenchê-lo. É uma "forma" em relação a uma única ocorrência empírica. Assim Benjamin:

O tempo da história é infinito em todas as direções e incompleto em todos os momentos. Isso significa que nenhum evento empírico particular é concebível que tenha uma relação necessária com a situação cronológica em que ocorre. O tempo 
da ocorrência empírica é apenas um formulário, mas - o que é mais importante - é um formulário que, como tal, nunca poderá ser preenchido. $\mathrm{O}$ acontecimento não satisfaz a natureza formal do tempo em que ocorre. (BENJAMIN, 1982, p. 168. Tradução nossa).

A natureza formal do tempo histórico não é algo que une e contem os eventos únicos, mas o que os determina. Esse acontecimento que está incompleto nos fenômenos individuais é, por outro lado, completado no "sentido da história", tem um "mais", ele é uma "ideia". Ele "forma" os eventos históricos individuais. Na "ideia" o tempo é cumprido, nele a forma é "incluída". Esta ideia é, para Benjamin, o "tempo messiânico": "Este acontecimento que se realiza no sentido da história é, por outro lado, inteiramente indeterminado no plano empírico - isto é, uma ideia. Esta ideia do tempo cumprido é a ideia histórica que domina na Bíblia: o tempo messiânico" (BENJAMIN, 1982, p. 169. Tradução nossa). Seguindo o texto, neste ponto Benjamin introduz a diferença entre Trauerspiel e tragédia. Se o tempo trágico exige sua realização e isso acontece para o herói trágico com a morte com que se cumpre seu trágico destino; isso não significa que isso seja feito em termos messiânicos. $O$ herói trágico, de fato, não pode escapar do contexto da culpa natural precisamente porque não há lado redentor no destino. Ele mostra a insuficiência da realização individual e se refere à messiânica. $\mathrm{O}$ tempo do Trauerspiel, por outro lado, não só não entende a forma, mas não conhece aquele ponto, aquele momento que a supera e determina. $\mathrm{O}$ tempo do Trauerspiel não se cumpre, mas se repete como em um jogo. A própria morte não acaba, mas torna-se fantasmagórica e reflexo entre imagens que continuam a remeter umas às outras: "O tempo do Trauerspiel moderno não está completo, mas acabou. Não é individual sem ser historicamente universal. O Trauerspiel é uma forma anfíbia em sentido estrito. A generalidade do seu tempo não é mítica, mas espectral" (BENJAMIN, 1982, p. 169. Tradução nossa). Precisamente deste último e de sua inconclusividade, como o próprio Benjamin lembra, existe uma lacuna que não permite que significante e significado se juntem. É neste ponto que Benjamin introduz o problema da linguagem. Na verdade, o que "resta" no Trauerspiel após o esgotamento do seu jogo de representação? Benjamin responde: "O resto do Trauerspiel chama-se música. Talvez - como a tragédia indica a passagem do tempo histórico para o tempo dramático - o Trauerspiel esteja situado no ponto em que o tempo dramático passa para o tempo da música" (BENJAMIN, 1982, pp. 170-171. Tradução nossa). Se por um lado a linguagem da tragédia não sofre transformações, porque nela a palavra é pura e está na sua "origem" e precisamente por isso o seu significado é unívoco; por outro lado, no Trauerspiel a palavra parte de sua origem e passa a ser não apenas cindida, mas também deriva de referências e significações e, portanto, ambígua. É a música interrompe que interrompe esse reenvio. Para Benjamin, porém, ela não entra como apoteose final de um círculo, não passa pela aflição da natureza e depois se fecha novamente para pousar novamente no "mundo puro das palavras" porque o Trauerspiel passa pelo som da natureza, de seu lamento e não sai ileso, mas leva os seus rastros. Não há reapropriação do perdido, apenas o sinal desse luto. O Trauerspiel é, neste sentido, o que "descreve o caminho que vai do som natural, passando pelo lamento, até à música" (BENJAMIN, 1993, p. 175. Tradução nossa). Representa este luto, mas através da música, no som que reproduz o lamento, encena também a sua redenção. Não é difícil vislumbrar nessa polaridade as correspondências entre linguagem e história, que serão abordadas nos outros dois textos importantes da produção inicial de Benjamin, Sobre a linguagem em geral e sobre a linguagem do homem e A tarefa do tradutor. Polaridade que se joga inteiramente a partir 
da "linguagem pura", de sua integridade ou de sua fragmentação. No tempo do herói trágico, como aqui se delineia, pode-se ver também o desenvolvimento futuro do momento revolucionário que realiza, ainda que individualmente, uma interrupção messiânica. A sua culpa é querer transformar o tempo individual em tempo histórico. Ele morre porque "ninguém pode viver em tempo integral". O ponto onde os dois extremos, o tempo individual e o tempo histórico se encontram, é o ápice e o ponto culminante da tragédia, a morte do herói.

Mas é num artigo publicado por Benjamin em 1915, A vida dos estudantes, que se podem delinear os primeiros traços que o levará a formular a própria teoria do Jetztzeit:

Existe uma concepção de história que, confiando em o infinito do tempo, distingue apenas o ritmo, a velocidade dos homens e as épocas, que correm mais rápido ou mais devagar nas trilhas do progresso. A esta concepção correspondem a incoerência, a imprecisão e a falta de rigor das reivindicações que faz para o presente. Em vez disso, essas nossas considerações referem-se a um estado específico, no qual a história repousa como uma coleção em um ponto focal, e ao qual as imagens utópicas dos pensadores sempre aludiram. [...] A história tem a tarefa de dar sua forma pura e absoluta ao estado imanente de perfeição, de tornálo visível e soberano no presente. Mas não é possível determinar esse estado recorrendo a uma descrição pragmática de fenômenos particulares (instituições, costumes, etc.), dos quais realmente escapa, só podem ser apreendidos em sua estrutura metafísica, como o reino messiânico ou a ideia francesa de revolução. (BENJAMIN, 1993, p. 137. Tradução nossa).

Se a primeira parte da breve reflexão de Benjamin visa inteiramente criticar um conceito de história que se inclina para o progresso como meta ideal a ser alcançada, que cataloga suas épocas como etapas evolutivas; é um "ponto focal", ao contrário, que está no centro e marca as diferentes concepções da história de Benjamin. É aquele akmé mencionado nos Materiais Preparatórios, "aquele estado imanente de perfeição" que antecipa, neste sentido, a "plena posse das formas", que o historiador deve ser capaz de apreender. Também neste texto, podemos ver como para o jovem Benjamin isso não se dá por uma atitude contemplativa ou pragmática, mas crítica e até profética. Pode-se enfatizar também como já existe neste texto a comparação entre o reino messiânico e a revolução francesa que é retomada nas Teses. E é interessante comparar essa imagem utópica de um jovem que se professava anarquista ${ }^{17} \mathrm{com}$ a de sua idade mais madura, caracterizada pela "virada materialista". É assim que descreve o sentido da utopia política nos Materiais Preparatórios: "lançar raios de luz sobre o setor que merece ser destruído" (BENJAMIN, 1997, p. 89. Tradução nossa). Esse ser destrutivo da utopia assume nas Teses os traços de uma "psicologia do caráter destrutivo". É num texto de 1931 intitulado $O$ caráter destrutivo que Benjamin descreve os traços dessa personalidade singular. A urgência que aqui emerge é de uma condição em que se torna obrigatória a consideração de um ponto de ruptura no curso histórico. A crise se manifesta com toda sua impetuosidade e, como na terminologia grega antiga, indica a "situação crítica" em que um paciente melhora ou morre, representando um possível ponto de inflexão ou de virada. O "caráter destrutivo" entra em cena e surge como o único solucionador possível. Ele é descrito como uma personagem perturbadora, desestabilizadora e infatigável, como aquela pessoa que, entrando em nossas vidas, causa os maiores transtornos. Se torna urgente "abrir espaço", "limpar", onde vê um continuum ele sente a necessidade de "desenraizar" e dilacerar. Seu desejo é deixar 
claro, iluminar o passado, até mesmo os vestígios de sua destruição devem ser eliminados. Ao contrário da "do homem-custódia" que se entrincheirou no seu "invólucro forrado", no seu interior rodeando-se de pequenas bugigangas que sinalizam continuamente ao dono os seus rastros, se houvesse um material para esta personagem seria o vidro: nele, de facto, todos os traços desaparecem, toda presença "aurática", assim como a barreira interna-externa e todo segredo em sua transparência evanesce. Esta personagem também tem uma alma preventiva fundamental porque vê a destruição iminente no que mostra fissuras e intervém nos "ritmos da natureza". De fato, com espírito histórico, ele entende como tudo o que parece sólido e estável é, na verdade, construído e está pendurado em um fio. O "caráter destrutivo", neste sentido, não se submete a nenhuma ordem dada, muito menos a concepções fatalistas. Ele não apaga o que foi definitivamente, mas o "cita", tirando-o de seu contexto. Ele não vê "nada duradouro", mas justamente por isso vê "rotas de fuga" em todos os lugares:

Mesmo onde os outros se chocam com paredes e montanhas, ele vê a saída. [...] E como ele vê saídas em todos os lugares, ele sempre se encontra em uma encruzilhada: nenhum momento pode saber o que o próximo trará. Reduz a escombros o existente, não pelos escombros, mas pela saída que os atravessa. (BENJAMIN, 2002, p. 522. Tradução nossa).

É seu instinto revolucionário, de fato, que o empurra a destruir, a parar por um momento naquela suspensão, naquele monte de entulho em que ele vê a abertura de novos caminhos possíveis. O caráter revolucionário, apesar de seu lado destrutivo, é, ao mesmo tempo, marcado por certa melancolia que rege todos os nascidos sob Saturno como Benjamin, o mais lento dos planetas. A doença negra, que caracteriza os ávidos e incansáveis trabalhadores da terra, mas também pensadores e revolucionários: "O caráter destrutivo não vive pelo sentimento de que a vida merece ser vivida, mas porque não vale a pena suicidar-se" (BENJAMIN, 2002, p. 522. Tradução nossa). Mas agora em uma situação de êxtase, em que o que foi destruído nos olha reduzido a escombros, como devemos nos comportar? É necessário relembrar o lema de Benjamin dos Materiais Preparatórios: "Como conciliar a crítica do passado com a sua salvação? Manter estável a eternidade dos acontecimentos históricos significa: ater-se à eternidade de sua transitoriedade" (BENJAMIN, 1997, p. 92. Tradução nossa). O que é necessário, portanto, é fixarmo-nos nesta transitoriedade, neste limiar que não é fronteira não com uma necessidade "construtiva", mas no horizonte livre de possibilidades que ele mesmo cria. Derridianamente poderíamos dizer que é um evento sem horizonte de espera aquele em que devemos parar.

O caráter destrutivo não cria para si mesmo, não é empurrado de maneira finalística em sua ação, mas é um responsável que deixa o espaço livre para se abrir a seu possível novo uso. É aqui e a esse aspecto positivo da destruição que podemos conectar outro texto de Benjamin, Experiência e Pobreza. Aqui podemos ver como, a partir de uma perda total de valores e de uma pobreza constitutiva da transmissibilidade da experiência, até a barbárie pode abrir um novo espaço:

O que é o bárbaro induzido pela pobreza da experiência? Ele é induzido a recomeçar; começando com o Novo; enfrentar o Pouco: construir a partir do Pouco e, além disso, não olhar nem para a direita nem para a esquerda. Entre os grandes criadores sempre houve os implacáveis, que antes de tudo fizeram uma varredura limpa. Na verdade, eles queriam ter uma mesa de desenho, eram construtores. (BENJAMIN, 2002, p. 540. Tradução nossa). 
Estas personagens destrutivas e construtivas ao mesmo tempo são, para Benjamin, Descartes com seu "cogito ergo sum", Einstein com sua superação de Newton, Klee com seus desenhos de engenharia, Scheerbart com suas construções de vidro, Brecht com seu teatro épico. Todos eles têm uma sensação de "pobreza de experiência":

Isso não deve ser entendido como se os homens fossem a uma nova experiência. Não, eles querem ficar isentos de experiências, eles querem um ambiente no qual possam trazer à tona sua pobreza, a externa e, em última instância, também a interna, de forma clara e clara que saia algo decente disso. Os homens nem sempre são ignorantes ou inexperientes. Muitas vezes podemos dizer o contrário: eles "devoraram" tudo, a "kultur" e o homem, e ficaram mais do que cheios e cansados disso. (BENJAMIN, 2002, p. 543. Tradução nossa).

Todos esses personagens, todas essas máscaras são revolucionárias como Blanqui ${ }^{18}$. Eles engolfam a Kultur e o viver burguês do século XIX, a separação entre dentro e fora, individual e coletivo e veem, com certa antevisão em relação aos outros, nessas polarizações e onde tudo está desmoronando, a chance de minar presente e seus estatutos e de abrir-se a novos espaços. É interessante notar como essa "veia destrutiva" com implicações positivas que Benjamin tanto apreciava, foi advertida e destacada pelo mesmo amigo e teólogo judeu Scholem, que se expressou assim a esse respeito:

A nobre e positiva violência da destruição - segundo ele negligenciada por muito tempo na apoteose unilateral, adialética e amadora do elemento criador - torna-se agora o aspecto da redenção relacionado com a imanência do mundo, que se realiza na história do trabalho humano. (BENJAMIN, 2007, p. 106. Tradução nossa).

Como escreve Benjamin é necessário destacar "as forças destrutivas que estão na ideia de redenção" (BENJAMIN, 1997, p. 93. Tradução nossa). Essa violência positiva, essa "nobre destruição" é a única que permite, a partir de seus escombros e ruinas, uma nova história dos possíveis esquecidos do passado que não seja arrastada nas trilhas do progresso, mas iluminada pela "ideia de redenção".

Em conclusão, podemos dizer que, embora a Jetztzeit apareça como um dos elementos mais "perturbadores" e difíceis de enquadrar da concepção benjaminiana do tempo, que com uma feliz expressão Marramao define "familiarmente estrangeiro" ou "enigmaticamente óbvio", ele representa o verdadeiro coup de théâtre do conceito da história benjaminiana e está presente como elemento subversivo e detonador, embora em forma germinativa, desde os textos juvenis de sua elaboração. É em um presente intrinsecamente intervalado de instantes revolucionários em que o passado que nunca existiu pode, em um determinado momento, brilhar no "agora". Aquele Jetztzeit que cintila como relâmpago, como chance de ser aproveitado, como tempo kairológico, constitui a verdadeira e única possibilidade de redenção, a estrela cometa para os perdedores de todos os tempos.

\section{REFERÊNCIAS}

BENJAMIN, W. Angelus Novus. Saggi e frammenti, trad. it. di R. Solmi, Torino: Einaudi, 1962.

BENJAMIN, W. Metafisica della gioventù. Scritti 1910-1918, a cura di G. Agamben, trad. it. di G. Backhaus, M. Bertolini Peruzzi, G. Carchia, G. Gurisatti, A. Marietti Solmi, Torino: Einaudi, 1993. 
BENJAMIN, W. Ombre corte. Scritti 1928-1929, a cura di G. Agamben, trad. it di G. Backhaus, M. Bertolini Peruzzi, G. Carchia, G. Gurisatti, A. Marietti Solmi, Torino: Einaudi, 1993.

BENJAMIN, W. Sul concetto di storia, trad. it di Bonola e Ranchetti. Torino: Einaudi, 1997.

BENJAMIN, W. Opere complete IV. Scritti 1930-1931, a cura di R. Tiedemann e H. Schweppenhäuser, ed. it. a cura di E. Ganni con la collaborazione di H. Riediger, Torino: Einaudi, 2002.

BENJAMIN, W. Opere complete IV. Scritti 1932-1933, a cura di R Tiedemann e H. Schweppenhäuser, ed. it. a cura di E. Ganni con la collaborazione di H. Riediger, Torino: Einaudi, 2002.

BLUMENBERG, H. Paradigmi per una metaforologia, tr. it. di Maria Vittoria Serra Hansberg, Milano: Raffaello Cortina, 2009.

BODEI, R., Le malattie della tradizione. Dimensioni e paradossi del tempo in Walter Benjamin in Walter Benjamin. Tempo storia linguaggio, a cura di Lucio Belloi e Lorenzina Lotti, Roma: Editori Riuniti, 1983.

BONOLA, G., “La porta di ogni istante”. In L'ospite ingrato, Macerata: Quodlibet, 2013.

DESIDERI, F., La porta della giustizia, Bologna: Pendragon, 1995.

GAGNEBIN, J. M, Walter Benjamin, Os cacos da História. São Paulo: Editora Brasiliense, 1993.

MARRAMAO, G., Kairos, Apologia del tempo debito, Roma: Laterza, 2005.

MARRAMAO, G. La passione del presente, Torino: Bollati Boringhieri, 2008.

MORONCINI, B. L'eccedenza del presente. In: Discipline filosofiche, v. 4 n. 1, p. 114, 1994.

SCHOLEM, G. Walter Benjamin e il suo angelo. Milano: Adelphi: 2007.

Notas

1 É na primeira edição do Angelus Novus em 1962 que Solmi traduz Jetztzeit como "Tempo-ora": "A história é o objeto de uma construção em que o tempo não é homogêneo e novo, mas cheio de "tempo agora". (BENJAMIN, 1962, p. 77. Tradução nossa).

$2 \mathrm{Na}$ reedição subsequente de 1981, novamente editada pelo próprio Solmi, o termo é traduzido como "atualidade". (BENJAMIN, 1962, p. 83. Tradução nossa).

3 Esta é a tradução de Jetztzeit feita por Bonola e Ranchetti, que motivaram a sua escolha da seguinte forma: "Traduzimos com este expediente gráfico (agora em itálico) todas as vezes que Jetztzeit aparece no texto e nos materiais, termo que geralmente significa: 'tempo presente', ou 'a era de hoje', mas que, a nosso ver, Benjamin carregou com um valor mais atual e preciso". (BENJAMIN, 1997, p. 47. Tradução nossa).

4 Assim fala Benjamin na tese XVIII: "O historicismo contenta-se em estabelecer um nexo causal entre os diferentes momentos da história. Mas nenhum estado é, de fato, como causa, já histórico. Tornou-se tão postumamente devido a circunstâncias que podem estar a milhares de anos de distância. O historiador que se muda daqui deixa de deixar a sucessão de circunstâncias fluir por entre os dedos como um rosário". (BENJAMIN, 1997, p. 57. Tradução nossa).

5 É somente o Jetztzeit que, segundo Fabrizio Desideri, "redime, erlöst, liberta os eventos das cadeias da necessidade do passado: de ser encerrado nele, maldito em terem sido assim e nunca poderem ser de outra forma". (DESIDERI, 1995, p. 153. Tradução nossa).

6 Assim Bonola e Ranchetti falam a respeito deste material que completa a edição italiana das Teses de 1997: "Esta seleção deveria originalmente ser contida em um envelope encontrado entre os papéis deixados por Benjamin, complementado com folhas dispersas tematicamente relevantes. Estes são textos de origem diferente (incluindo transcrições de passagens já selecionadas para a Passagen-Werk) reunidos por Benjamin para a atual elaboração das teses, mas também com vistas a uma reflexão mais aprofundada sobre o tema". (BENJAMIN, 1997, p. 71. Tradução nossa).

7 Historiadores e políticos compartilham a mesma missão: antever o presente e olhar para trás. Benjamin explica assim o conceito de presente que se desprende irremediavelmente de toda posse: "Este presente, por estranho que pareça, é objeto de uma profecia. Que, portanto, não anuncia algo que virá. Ele apenas permite que você saiba o que o sino tocou. E o político sabe melhor do que ninguém o quanto, para dizer isso, é preciso ser profeta. Encontramos esse conceito de presente muito precisamente em Turgot. 'Antes de 
sabermos sobre um determinado estado de coisas - escreve ele - isso já mudou várias vezes. Portanto, é sempre tarde demais para sabermos o que aconteceu. E por isso pode-se dizer da política que ela se reduz, por assim dizer, a antever o presente'. O mesmo pode ser dito da história". (BENJAMIN, 1997, p. 75. Tradução nossa).

8 Assim Jeanne Marie Gagnebin comenta a necessidade de Benjamin de refundação de uma nova historiografia: "Como pensar o tempo da História? Como escrever uma historiografia que não faça do presente o resultado previsível de um desenvolvimento necessário - mas que saiba revelar o possível - o que foi possível um dia no passado e o que é possível hoje?" (GAGNEBIN, 1993, p. 20).

9 Assim Benjamin descreve a prontidão necessária para o historiador materialista: "Presença de espírito como aquilo que salva; presença de espírito na captura de imagens fugazes; presença de espírito e arresto". (BENJAMIN, 1997, p. 89. Tradução nossa).

10 As metáforas utilizadas em todos os textos benjaminianos, neste sentido, respondem também a esta necessidade de uma linguagem mais concreta e ativa. Todas sugerem uma oportunidade necessária, uma urgência que tira o fôlego: clarão, estopim, relâmpago, explosão, faísca são apenas algumas das metáforas explosivas do arsenal de Benjamin. Poderíamos chamá-las com Blumenberg de "metáforas orientadoras", pois trata-se de uma linguagem analógica ainda não silenciada pela superação da puramente lógicoconceitual. Na verdade, elas manifestam toda a sua força e significação em antítese aos sofismas filosóficos típicos que o autor não hesita em definir enganes.

11 Assim Jeanne Marie Gagnebin comenta a este respeito: "Na tradição teológica judaica, e especialmente na tradição mística da Cabala, a interpretação não pretende delimitar um sentido unívoco e definitivo; ao contrário, o respeito pela origem divina do texto impede sua cristalização e sua redução a um significado único" (GAGNEBIN, 1993, p. 35).

12 Assim Benjamin a este respeito: "A grande revolução trouxe um novo calendário. $\mathrm{O}$ dia inaugural de um calendário atua como compêndio histórico acelerado. Afinal, é sempre o mesmo dia que volta em figura nos dias de festa, que são dias de rememoração". (Ivi, p. 47-49. Tradução nossa).

13 Nem toda história, no entanto, é simplesmente conservadora e não apenas o historicismo culmina legitimamente na história universal, mas através do "princípio monadológico" uma história universal pode existir como uma "história de salvação". Assim Benjamin o descreve: "Nem toda história universal é necessariamente reacionária. É uma história universal sem princípio construtivo. O princípio construtivo da história universal permite que seja representado em histórias parciais. E, em outras palavras, um princípio monadológico existe na história da salvação". (BENJAMIN, 1997, p. 92. Tradução nossa).

14 Assim Gagnebin argumenta a este respeito: "O que ele sempre condenou na critica literária acadêmica é o fato de esta procurar a "verdade" nas "ideias eternas" e nos "valores atemporais", ao invés de captá-la na espessura da historicidade da obra". (GAGNEBIN, 1993, p. 34).

15 A este respeito Gianfranco Bonola argumenta: "É como se ele [Benjamin] sem ser matemático, tivesse intuído a teoria dos fractais. [...] Em cada pequeno detalhe se reproduz a estrutura que articula a maior parte na qual está contida, e assim sucessivamente para cada dimensão maior e para a dimensão máxima, que é a do objeto inteiro. Assim, é possível, lendo atentamente um pequeno detalhe, ter uma noção da grande dinâmica histórica". (BONOLA, 2013, p. 95. Tradução nossa).

16 Deste modo Benjamin fala desse corte que divide, mas fora de si. Ele retoma o mito de Apeles, que teria desafiado Protogenes a ser capaz de traçar uma linha ainda mais sutil por ele traçada: "A pré e a pós-história de um fato histórico aparecem nela graças à sua exposição dialética. [...] Torna-se tal porque a realidade age dentro dele. É por isso que o estado de fato histórico se polariza segundo sua pré e pós-história sempre de novo e nunca da mesma forma. E ele o faz fora de si mesmo, na própria realidade; com uma linha, dividida pelo corte de Apeles, experimenta sua divisão fora de si”. (BENJAMIN, 1997, p.120. Tradução nossa).

17 Simpatia anarquista que uniu Benjamin e Scholem. Desse modo, em uma carta de Benjamin a 
Scholem em 1916, o filósofo alemão motiva sua "virada" em relação ao seu anarquismo anterior: "[...] não penso em renunciar ao que havia argumentado antes, porque não tenho vergonha do anarquismo anterior, mas considero, sim, os métodos anarquistas inúteis, mas quanto aos objetivos comunistas considero-os absurdos e inexistentes. Isso não reduz em nada o valor da ação comunista, porque é a corretiva de seus objetivos e porque não

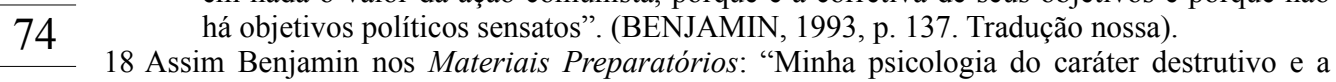
psicologia proletária do caráter destrutivo de Blanqui". (BENJAMIN, 1997, p. 89. Tradução nossa). 